\title{
Design of Smart Device with Android based Application for Self-defense and Self-protection-A Women Security Solution
}

\author{
Shrenika N. \\ B.E in CSE, BMSIT M \\ Banglore,India
}

\author{
Srivani P. Badala \\ Assistant \\ Professor,BMSIT M \\ Banglore, India
}

\author{
Sai Keerthana K. S. \\ B.E in CSE, BMSIT M \\ Banglore, India
}

\author{
Hamsa N. \\ B.E in CSE, BMSIT M \\ Banglore, India
}

\begin{abstract}
Security for women has become a major issue as the number of crimes over women and girls is increasing day-by-day. This proposed project describes women's safety and their security by using an electronic device to detect the problem, selfdefense\& alert authorities. It suggests a new perspective to use technology to protect women. In this project, an android based smartphone with an integrated feature that alerts and provides location-based information. It provides self-defense and SMS alert when a girl is in danger. The voice recognition will happen when the girl is shouting. It will recognize the voice and send to Raspberry $\mathrm{Pi}$ kit through a wireless connection. It also makes use of an accelerometer. The Raspberry Pi module will analyze the situation and send alert SMS with (GPS) Global positioning system location to Guardian or police station, generates an electric shock which can be used as self-defense and captures the image of the environment.
\end{abstract}

\section{Keywords}

Android, GSM, GPS, Women Safety, Accelerometer and camera Sensor.

\section{INTRODUCTION}

In Today's Scenario, the safety and security for women is in danger particularly in India. The rate of harassment, rapes, molestations, eve teasing and many misbehaving activities have been increasing day to day in many cities[1]. Even after taking certain measures, the Government is not able to provide any security for women. Hence, one of the ways to solve this issue is through self-defense, where women can protect herself by using a technology based applications and devices. The most primitive part of these applications are GPS tracking, sending SMS[2], spy-cameras. Many sensors have been implemented in these systems to monitor and alert the designated persons to save themselves during dangerous situations. For self-defense the system might be proposed to defend herself using shock generators, bulky belts. Android and iOS apps have also been integrated into these systems to collect and sink the data in real time, so that the alert assistance can be provided. Several researches are going on this and have designed wristbands, smart watch, etc. Titan Company has designed a first smart watch for women's safety called "ACT - App-Enabled Coordinates Tracker" which sinks tothe user's smart-phone and triggers and alerts when that recipient who has worn the watch is in danger [3].

In this proposed project, to provide women safety and security, an Android based application has been used to handle the situation during a crisis. This project is integrated with a microcontroller, sensors and mainly with shock generator circuit for self-defense. This system overcomes the limitations like network issues, feasibility and real time monitoring of the situation. In this project GPS tracking system and GSM module have been proposed which alerts and sends location based information. The project also integrates voice recognition system to detect the keyword like 'help', 'help me', 'danger' and matches it with the database during dangerous situations. It provides self-defense and SMS alert when a girl is in danger. The proposed system is built with the Raspberry Pi kit through a wireless connection implemented with accelerometer meter sensor during abnormal motions and the camera module captures the images in real time.. The Raspberry Pi module will analyze the situation alerts the guardian and nearby authorities. The Electric Shock generator module generates shock which helps in providing self-defense.

\section{EXISTING SYSTEM}

Table 1: Related work of the existing systems

\begin{tabular}{|c|c|c|c|}
\hline $\begin{array}{l}\text { Reference } \\
\text { s }\end{array}$ & Methodology & Advantages & $\begin{array}{l}\text { Disadvantage } \\
\mathrm{S}\end{array}$ \\
\hline [3] & $\begin{array}{l}\text { Android } \\
\text { application } \\
\text { which sends } \\
\text { messages to } \\
\text { emergency } \\
\text { contact using } \\
\text { GPS, GSM } \\
\text { module [4] }\end{array}$ & $\begin{array}{l}\text { Sends the } \\
\text { location } \\
\text { continuousl } \\
\text { y for every } \\
5 \text { minutes } \\
\text { till stop } \\
\text { button is } \\
\text { pressed }\end{array}$ & $\begin{array}{l}\text { Cannot be } \\
\text { used when the } \\
\text { mobile } \\
\text { network is not } \\
\text { available. } \\
\text { No } \\
\text { defense }\end{array}$ \\
\hline [1] & $\begin{array}{l}\text { GPS and GSM } \\
\text { integrated with } \\
\text { smart watches } \\
\text { are connected } \\
\text { via Bluetooth } \\
\text { to the smart - } \\
\text { phone[5] }\end{array}$ & $\begin{array}{l}\text { Provides a } \\
\text { high pitch } \\
\text { alarm } \\
\text { sound. } \\
\text { Gives the } \\
\text { notificatio } \\
\text { n when the } \\
\text { heart beat } \\
\text { goes above } \\
\text { a certain } \\
\text { range }\end{array}$ & Not reliable \\
\hline [2] & $\begin{array}{l}\text { As the shock is } \\
\text { generated the } \\
\text { AVR } \\
\text { microcontrolle } \\
\mathrm{r} \text { sends signal } \\
\text { towards GPS }\end{array}$ & $\begin{array}{l}\text { It is a } \\
\text { portable } \\
\text { device and } \\
\text { provides } \\
\text { self- } \\
\text { defense }\end{array}$ & $\begin{array}{l}\text { If girl fails to } \\
\text { press the push } \\
\text { button or } \\
\text { becomes } \\
\text { unconscious } \\
\text { its not worth }\end{array}$ \\
\hline
\end{tabular}




\begin{tabular}{|l|l|l|l|}
\hline & and GSM [6] & for safety. \\
\hline$[4]$ & $\begin{array}{l}\text { An advanced } \\
\text { artificial } \\
\text { intelligence, } \\
\text { security } \\
\text { system [7] }\end{array}$ & $\begin{array}{l}\text { Auto } \\
\text { receiving } \\
\text { call } \\
\text { module.It } \\
\text { uses audio } \\
\text { and video } \\
\text { recording } \\
\text { module }\end{array}$ & $\begin{array}{l}\text { To press the } \\
\text { mobile must } \\
\text { be in reach at } \\
\text { emergency }\end{array}$ \\
\hline
\end{tabular}

\subsection{Existing Apps}

Table 2: Existing Apps

\begin{tabular}{|l|l|l|l|}
\hline $\begin{array}{l}\text { SI } \\
\text { No }\end{array}$ & Name & Advantages & Disadvantages \\
\hline 1 & $\begin{array}{l}\text { Vith } \\
\text { App[8] U }\end{array}$ & $\begin{array}{l}\text { Alert messages } \\
\text { aresent to the } \\
\text { contact list to the } \\
\text { physical location } \\
\text { practicallyfeasible } \\
\text { to click the power } \\
\text { button twice } \\
\text { consecutively }\end{array}$ \\
\hline 2 & $\begin{array}{l}\text { Nirbhaya } \\
\text { App[9] }\end{array}$ & $\begin{array}{l}\text { Sends SMS alert } \\
\text { or call in a single } \\
\text { touch. Updates } \\
\text { every 300 meters }\end{array}$ & $\begin{array}{l}\text { False alarm when } \\
\text { power button is } \\
\text { pressed }\end{array}$ \\
\hline 3 & $\begin{array}{l}\text { My- } \\
\text { Safetypin[10] }\end{array}$ & $\begin{array}{l}\text { Update user with } \\
\text { the occurred } \\
\text { threats in the } \\
\text { locality }\end{array}$ & No alert message \\
\hline
\end{tabular}

\section{SYSTEMDESIGN AND METHODOLOGY}

The overall architecture of the system as shown in Figure 1 depicts the various features implemented like a camera which is used to capture the environment in which the women is subjected to danger, Electric shock generator that acts like a self-defense to protect herself on the spot. Different types of sensors such as light and pressure sensors that work on the defined logic and a voice recognition system that recognizes the woman's voice are implemented in this system. The system also sends a message to the guardian or the police station. This message includes the latitude and longitude of the person at the time of the attack.

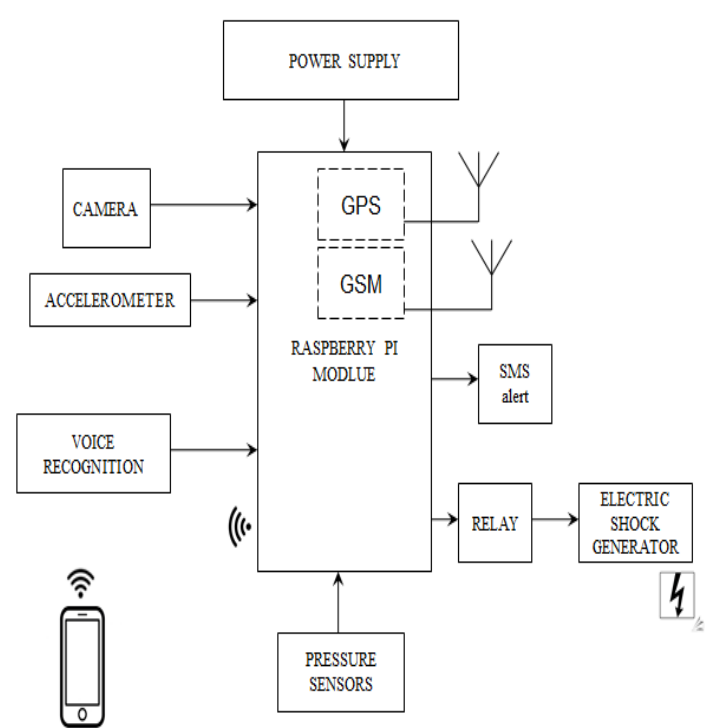

Fig 1:The snapshot of the circuit of the overall system

When the user shouts they keyword, the data will be sent as an input to the first web server. If the keyword matches the database, then all the modules (camera, shock generator, accelerometer) in the kit will be enabled. The data from these modules will be sent as a response to the second web server. From the web server, it will be sent to the guardian. The web server acts as an intermediate phase between the user and the guardian. The image of the surrounding and the latitude and longitude will be sent as a notification through the app as well as SMS will be sent to the guardian. In this way the device will be useful for women when in danger

\section{IMPLEMENTATION AND RESULTS}

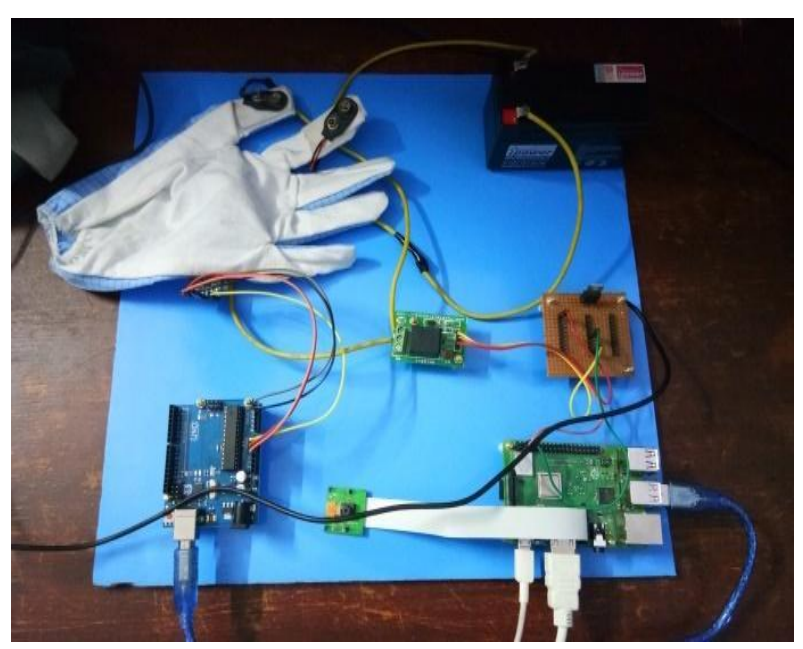

Fig 2: Snapshot of the circuit of the overall system

The results show that the prototype of the proposed safety system with sensors integrated with an android application assists and alerts the women in danger. Whenever the person calls for help when in danger, the keywords are recognized using the voice recognizer and camera module gets initiated. This in turns sends location-based messages to the guardian and respective individuals.

One of the new initiatives in this project is an implementation of the electric shock generator that generates a shock up to 12 volts. This gets activated when the keywords are matched 
with the database along with the other modules which act as a self-defense mechanism during the attack.

Figure 3 describes the user login page, when the login information is not correct or is not registered yet. The user will be directed to the registration page. Figure 4 shows how a SMS alert message is received bythe mentor or guardian.

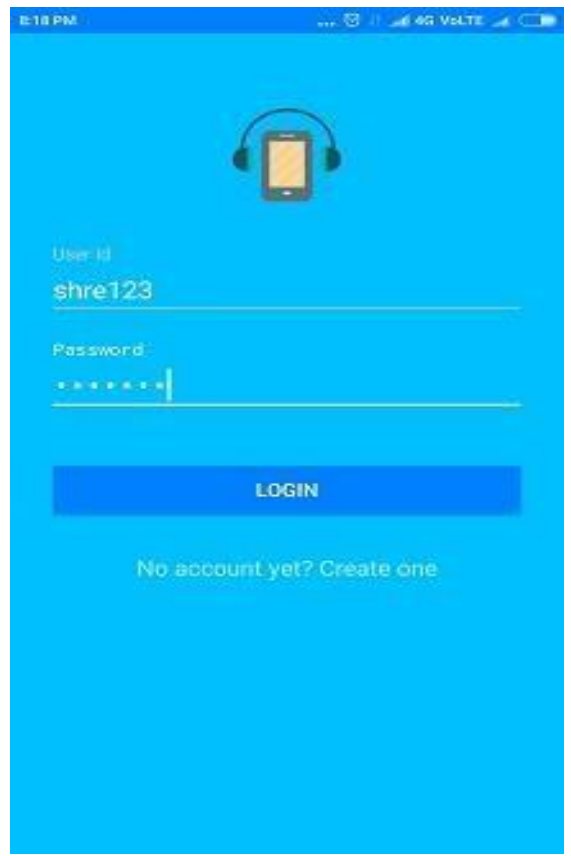

Figure 3:User login page

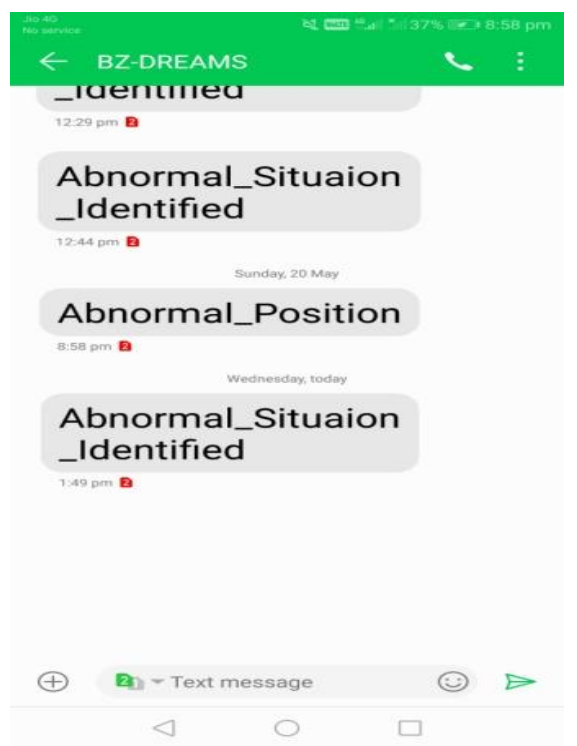

Figure4: SMS Alert received by the mentor

\section{CONCLUSION}

The problem of women's safety is increasing rapidly, soby implementing an effective android application to prevent such attacks by alerting the concerned guardians has been done. In this project work, a complete working model has been studied and instigated using a Microcontroller. This work includes the implementation of GPS, SMS gateway, voice recognition, shock generation mechanism, camera to capture the image of the surroundings. The women security system is the helpful tool to have self-defense for women.
By using this systematic prevention of incident is being carried out by using a shock model, accelerometer, these methods will be helpful to prevent the violence rather than communication. Communication through GPS \& GSM technology is the supplementary part to have help to the person. In future to have legal processing,video, information can be sent to the cops, State \& Central GovernmentTo have immediate punishment for the criminal.

\section{FUTURE ENHANCEMENT}

By encrypting the GOOGLE MAPS in the GPS sensor it can detect the area instead of latitude and longitude information. This proposed project sends the latitude and longitude of the current location as an alert notification as well as SMS to the guardian. As a future enhancement there is a need to encrypt the Google Maps with the security system and get the exact area of the user instead of the latitude and longitude.

By using Nano sized materials, the kit size gets reduced. The current scenario is that to develop a prototype of the women security system. By reducing the size of the materials, i.e., by using Nano sized materials the kit size can be reduced. Also,the researchers can aim towardsdesigning a portable device by using VLSI (Very-large-scale integration) technology. Instead of carrying a big kit the user can carry a portable device.

The device which has beendesigned, is having a high responsetime, i.e. when the user shouts the keyword using the voice recognition module the device takes more time to send an alert notification as a response. If this response time is reduced the device will be more efficient and reliable.

In remote areas where a network is not available, can have a siren module to make it more reliable. When there is no network in remote areas, the system won't be able to track the GPS and also notifications cannot be sent. In such case, a siren module will be helpful. The device will be more reliable when it is integrated with the siren module.

\section{ACKNOWLEDGMENT}

Thanks to the Guide, Co-coordinators for making this project successful

\section{REFERENCES}

[1] World Health Organization, "Global and regional estimates of violence against women: prevalence and health effects of intimate partner violence and nonpartner sexual violence, Geneva: WHO (2013).

[2] “One Touch Alarm System For Women's Safety Using GSM", International Journal of Science, Technology \&Management,Premkumar P, CibiChakkaravarthi R, Keerthana M, Ravivarma R, Sharmila T (2015)

[3] Available [Online] From June 2018. At https://www.titan.co.in/shoponline/watches/act_safety_watch

[4] "Abhaya: An Android app for the safety of women", IEEE INDICON 2015

[5] "A smart watch for women security based on IOT concept 'WATCH ME “, Second International Conference On Computing and Communications Technologies(ICCCT'17),2017

[6] "Smart Foot Device for Women Safety", IEEE Region 10 Symposium(TENSYMP), Bali,Indonesia 2016

[7] "All in one Intelligent Safety System for Women 
Security", International Journal of Computer Applications (0975 - 8887), Volume 130 - No.11, November 2015.

[8] Availbale [Online] From June 2018. At: https://www.tandfonline.com/doi/abs/10.108/13552074.2 015.1013669 ? $\mathrm{src}=$ recsys \&journalCode $=\operatorname{cgde} 20$

[9] Available [Online] From June 2018. At: https://economictimes.indiatimes.com/slideshows/techlife/use-these-mobile-apps-for-yoursafety/slideshow/46298858.cms

[10] Available [Online] From June 2018. At:http://www.thehindu.com/scitech/technology/nirbhaya-mobile-app-to-help-women-indistress/article4287011.ece 